\title{
ПРЕДПОСЫЛКИ ТЕХНОГЕННОЙ МЕТАМОРФИЗАЦИИ ИОННОГО СОСТАВА ВОДЫ Р. НАДЫМ В УСЛОВИЯХ ГЛОБАЛЬНЫХ КЛИМАТИЧЕСКИХ ИЗМЕНЕНИЙ
}

\author{
(С) 2020 г. А. О. Даниленко ${ }^{a, *}$, Л. С. Косменко ${ }^{a, * *}$, \\ О. С. Решетняк ${ }^{a, b}, * * *$, М. Ю. Кондакова ${ }^{a, * * * *}$ \\ аФГБУ “Гидрохимический институт”, Ростов-на-Дону, Россия \\ ${ }^{b}$ ФГОУ ВО “Южный федеральный университет”, Ростов-на-Дону, Россия \\ *e-mail: a.danilenko@gidrohim.com \\ **e-mail:l.kosmenko@gidrohim.com \\ ***e-mail: olgare1@mail.ru \\ ****e-mail: m.kondakova@gidrohim.com \\ Поступила в редакцию 04.02.2019 г. \\ После доработки 13.05.2019 г. \\ Принята к публикации 03.10.2019 г.
}

\begin{abstract}
Рассмотрены изменения гидрохимического режима р. Надым у г. Надым с начала регулярных наблюдений с 1955 по 2016 г. под влиянием антропогенного воздействия и глобальных климатических изменений. Показано, что для главных ионов с 1980 г. связи их концентраций с расходом воды ослабевают вплоть до незначительных, а также возникает нарушение естественных соотношений между главными ионами, наиболее ярко выражающееся в значительном увеличении содержания в речной воде сульфатов. Представлены данные о многолетней динамике главных ионов в основные фазы водного режима (весеннее половодье, летне-осенний период и зимняя межень). Выявлены многолетние сезонные изменения доминирующих катионов и анионов, отражающие возможность техногенной метаморфизации ионного состава воды р. Надым и смены ее химического класса. Рассмотрены вероятные причины наблюдаемых изменений: влияние сброса неочищенных сточных вод, атмосферного переноса соединений серы антропогенного и природного происхождения, загрязнение минерализованными пластовыми и нефтепромысловыми водами. Выдвинуто предположение, что повышенное поступление сульфат-ионов во все характерные фазы гидрологического режима, включая зимнюю межень, связано с загрязнением грунтовых сезонно-талых и межмерзлотных вод в результате фильтрации и утечки отходов бурения из шламовых амбаров за счет деградации их естественного гидроизоляционного слоя многолетнемерзлотных пород под действием глобальных изменений климата.
\end{abstract}

Ключевые слова: р. Надым, ионный состав речной воды, техногенная метаморфизация, антропогенное воздействие, глобальные изменения климата

DOI: $10.31857 / \mathrm{S} 2587556620010069$

\section{ВВЕДЕНИЕ}

В современной научной литературе сосуществуют альтернативные представления о соотношении влияния техногенных и природных факторов на химический состав природных вод севера Западной Сибири. С одной стороны, считают, что он формируется под воздействием интенсивного освоения нефтегазоконденсатных месторождений Надым-Тазовского междуречья [9]. С другой стороны, присутствуют сведения о низком уровне техногенного загрязнения территорий севера Западной Сибири. Здесь располагаются участки крупных рек, чья полноводность вместе с локальностью проявлений антропогенной нагрузки прак- тически нивелируют влияние на них хозяйственной деятельности. С этой точки зрения основные процессы, формирующие ионный состав крупных рек, - природные. Они обусловлены выветриванием химических веществ из горных пород и поступлением с поверхности водосборов, а техногенные процессы определяют гидрохимический состав только малых водотоков [13].

Оценку антропогенного влияния на химический состав природных вод традиционно проводят на основе сравнения фактически наблюдаемых концентраций растворенных веществ с ПДК. Однако такой подход не вполне корректен для случаев, когда естественное содержание раство- 
ренных химических веществ значительно ниже их ПДК. В таких условиях формальные комплексные оценки не способны уловить формирующиеся проблемы, например, увеличения содержания ионов в маломинерализованных водах северных рек, закисления или смены класса вод в результате техногенной метаморфизации. В настоящей статье внимание уделено многолетней динамике главных ионов и особенно сульфатов в р. Надым. ПДК сульфатов для водных объектов рыбохозяйственного значения составляет 100 мг/дм ${ }^{3}$, что для ультрапресных вод западносибирских рек является очень значительной величиной, в разы превышающей природное содержание. Влияние антропогенных факторов (нефтегазодобыча, проведение буровых работ, сероочистка углеводородов, аварийные сбросы минерализованных пластовых вод и их захоронение в скважинах и т.д.) на ионный состав поверхностных вод Крайнего Севера Западной Сибири усугубляется процессами, связанными с глобальными климатическими изменениями, в частности усилением водообмена между поверхностными и подземными водами за счет формирования сквозных таликов, термоэрозии многолетнемерзлотных грунтов и т.Д. В воде р. Надым были выявлены многолетние тренды содержания некоторых главных ионов, возможные причины которых разбираются в данной статье.

\section{ОБЪЕКТ ИССЛЕДОВАНИЯ, МАТЕРИАЛЫ И МЕТОДЫ}

Гидрохимические материалы, использованные в работе, представляют собой многолетние ряды данных о концентрациях главных ионов (сульфаты, хлориды, гидрокарбонаты, кальций, магний и сумма одновалентных щелочных катионов) в воде р. Надым у г. Надым с 1955 по 2017 гг., полученные Государственной наблюдательной сетью (ГНС). Архивные гидрологические материалы о среднесуточном расходе воды и даты отбора проб взяты из таблиц гидрологических ежегодников, режимно-справочного банка данных "Качество поверхностных вод”, а с 2008 по 2016 гг. - из автоматизированной информационной системы государственного мониторинга водных объектов Росводресурсов (https://gmvo.skniivh.ru).

Объектом исследования является р. Надым, которая берет начало из оз. Нумто на Сибирских Увалах, течет с юга на север, пересекая ландшафты северной тайги и лесотундры, и впадает в южную часть Обской губы Карского моря. Длина реки - 545 км, площадь водосбора - 64 тыс. км², средний слой стока 290 мм/год. В пункте наблюдений ГНС у г. Надым расстояние от устья составляет 109 км, площадь водосбора - 48 тыс. км² [21].
В питании р. Надым главную роль играют талые снеговые воды (54\%). Наличие многолетней мерзлоты придает водному режиму своеобразие: Надым многоводен в периоды снеготаяния и маловоден зимой. Начинается половодье в конце мая-начале июня, достигает пика через две недели и завершается в среднем в начале третьей декады июля (60-70 дней). Летне-осенняя межень нередко прерывается дождевыми паводками. Ледостав в северной части бассейна, где расположен г. Надым, наступает в начале третьей декады октября и продолжается в среднем 230 дней [14].

На территории бассейна распространена многолетняя мерзлота [5]. Его высокоширотное расположение обуславливает специфический состав местных природных вод, которые обладают малой минерализацией и по типу преобладающих катионов и анионов относятся преимущественно к гидрокарбонатно-кальциевым. Многолетнемерзлые породы ограничивают поступление в реки и озера более минерализованных подземных вод, а почвенный покров хорошо промыт и обеднен солями [7].

Многолетние ряды данных были проанализированы с использованием MS Excel 2010 и Statistica 13.3. На первом этапе вариационные ряды гидрохимической информации были предварительно подготовлены: исключены аномально высокие значения концентраций [4] и заменены нули на полусумму пределов определения и обнаружения вещества соответствующей аналитической методикой.

Подготовленные ряды многолетних данных использованы для анализа связей между среднесуточным расходом воды и концентрацией того или иного иона. Связи были получены для данных, разбитых на два периода: условно фоновый (1955-1980 гг.), с открытия пункта мониторинга на р. Надым у г. Надым до начала широкомасштабного освоения нефтегазовых месторождений [2]; современный - с 1981 по 2017 гг. Рабочая гипотеза состояла в том, что при отсутствии значимых антропогенных воздействий характер такой связи устойчив, современный период должен слабо отличаться от условно-фонового, а для главных ионов он может быть описан традиционными логарифмическими или степенными функциями. Антропогенное воздействие ослабляет влияние расхода воды на содержание главных ионов, в результате чего связи могут оказаться нарушенными в зависимости от глубины таких “возмущений”, вызванных влиянием человеческой деятельности на водосборе.

Для оценки многолетней динамики концентраций главных ионов в характерные гидрологические сезоны проведен регрессионный анализ с построением линейных функций, которые дают общее представление о направлении процесса, хотя и далеко не всегда отражают его сложность. 
Разделение вариационных рядов на гидрологические сезоны проведено по датам соответствующих измерений. В рамках данной работы принято, что зимняя межень на р. Надым начинается в третьей декаде октября предшествуюшего года и продолжается до первой декады мая; за старт весеннего половодья принята вторая декада мая, за окончание - третья декада июня; фаза летнеосенней межени охватывает период с первой декады июля по вторую декаду октября [14].

\section{РЕЗУЛЬТАТЫ ИССЛЕДОВАНИЯ}

Одной из предпосылок техногенной метаморфизации природных вод является увеличение их минерализации, возможное изменение кислотности среды, коэффициентов активности ионов и другие значимые последствия. Река Надым относится к северным маломинерализованным водам гидрокарбонатного класса, кальциевой группы по классификации О.А. Алекина. Изменение общей минерализации в пределах до 200 мг/дм ${ }^{3}$, а чаще и до 50 мг/дм ${ }^{3}$ в течение года незначительно, максимальное ее значение отмечается к концу зимней межени. Основными ионами во все периоды года являются $\mathrm{HCO}_{3}^{-}$, а также $\mathrm{Ca}^{2+}$ и $\mathrm{Mg}^{2+}$ [10]. Поэтому, даже сравнительно небольшие, не превышающие ПДК изменения минерального состава речной воды здесь становятся заметны. Признаком антропогенного влияния на него является не только нарушение естественных соотношений между главными ионами, но и утрата связи их концентраций с расходом воды.

Оценка характера связей “расход-концентрация” для главных ионов показала, что наилучшей аппроксимации можно добиться, используя степенные функции (рис. 1). Качество аппроксимации невысокое, однако для катионов и анионов можно выделить общие закономерности. Концентрации двухвалентных катионов металлов до 1980 г. обнаруживают связь с расходом воды, но в современный период эта связь утрачена. Для одновалентных катионов эта связь слабая и, вероятно, на ее качество существенно влияет расчетный способ определения их содержания, в результате чего на него падает вся сумма погрешностей, накапливаемых при отдельных определениях главных ионов [1]. Для катионов кальция коэффициент корреляции $\mathrm{r}$ со значениями среднесуточного расхода равен 0.79 , а коэффициент аппроксимации $\left(r^{2}\right)-0.63$ для периода с 1955 по 1980 гг. включительно, после чего он начинает снижаться вплоть до незначительной степени связи. Для периода 1981-2017 гг. удовлетворительную аппроксимацию подобрать не удалось. Для концентраций магния в условно-фоновый период качество аппроксимации ниже: $r=0.71, r^{2}=0.50$, для современного периода удовлетворительную аппрокси- мацию подобрать также не удалось. Самое низкое качество связи "расход-концентрация" установлено для суммы ионов натрия и калия $\left(r=0.50, r^{2}=\right.$ $=0.25)$.

Среди анионов статистически значимая связь между концентрациями ионов и среднесуточными расходом воды характерна для гидрокарбонатов. Она сильная $\left(r=0.87, r^{2}=0.75\right)$, но также имеет порог времени, когда перестает существовать. Так же, как и для катионов кальция и магния, таким порогом следует считать 1980 г.

Сульфаты и хлориды утрачивают связь с расходом воды, вероятно, еще до начала инструментальных наблюдений, так как для них связи были статистически незначимы с самого начала периода наблюдений. Помимо этого, на графике сульфатов видно, что основное количество измерений с наибольшими значениями концентраций сосредоточены во втором временно́м интервале, что однозначно свидетельствует о появлении многолетнего тренда.

При значительном антропогенном воздействии, которое в данном случае выступает в качестве приоритетного направленно действующего фактора, корреляционная связь химического стока рек с водным стоком ослабевает вплоть до незначительной [8]. В меньшей степени это заметно для ионов, поступающих в процессе растворения пород литогенной основы речного бассейна р. Надым и менее подверженных антропогенному воздействию, - катионов кальция и анионов гидрокарбонатов. В большей степени нарушения проявляются в гидрохимическом режиме сульфатов, которые более уязвимы к антропогенному воздействию. Основными источниками сульфатных ионов в природных водах можно назвать вымывание их из осадочных пород, процессы отмирания и окисления веществ растительного и животного происхождения, привнос с дождевыми водами и мелкими распыленными брызгами морской воды. Кроме природных источников важную (а иногда и доминирующую) роль играют также антропогенные: сера, пирит, сульфидные составляющие руд меди, свинца и цинка, сероочистка угля, нефти и газа. Аэробные условия атмосферы, поверхностных вод и грунтовых вод активного водообмена также стимулируют протекание окислительных превращений восстановленных форм серы до образования сульфат-иона [3].

Выведение сульфат-ионов из солевого оборота поверхностных вод сравнительно невелико и обеспечивается химическими и биологическими механизмами, которые для высокоширотных территорий имеют низкие скорости. Первый механизм связан с химическими процессами выведения серы в результате образования нерастворимых соединений при взаимодействии с катионами кальция. В маломинерализованных северных во- 

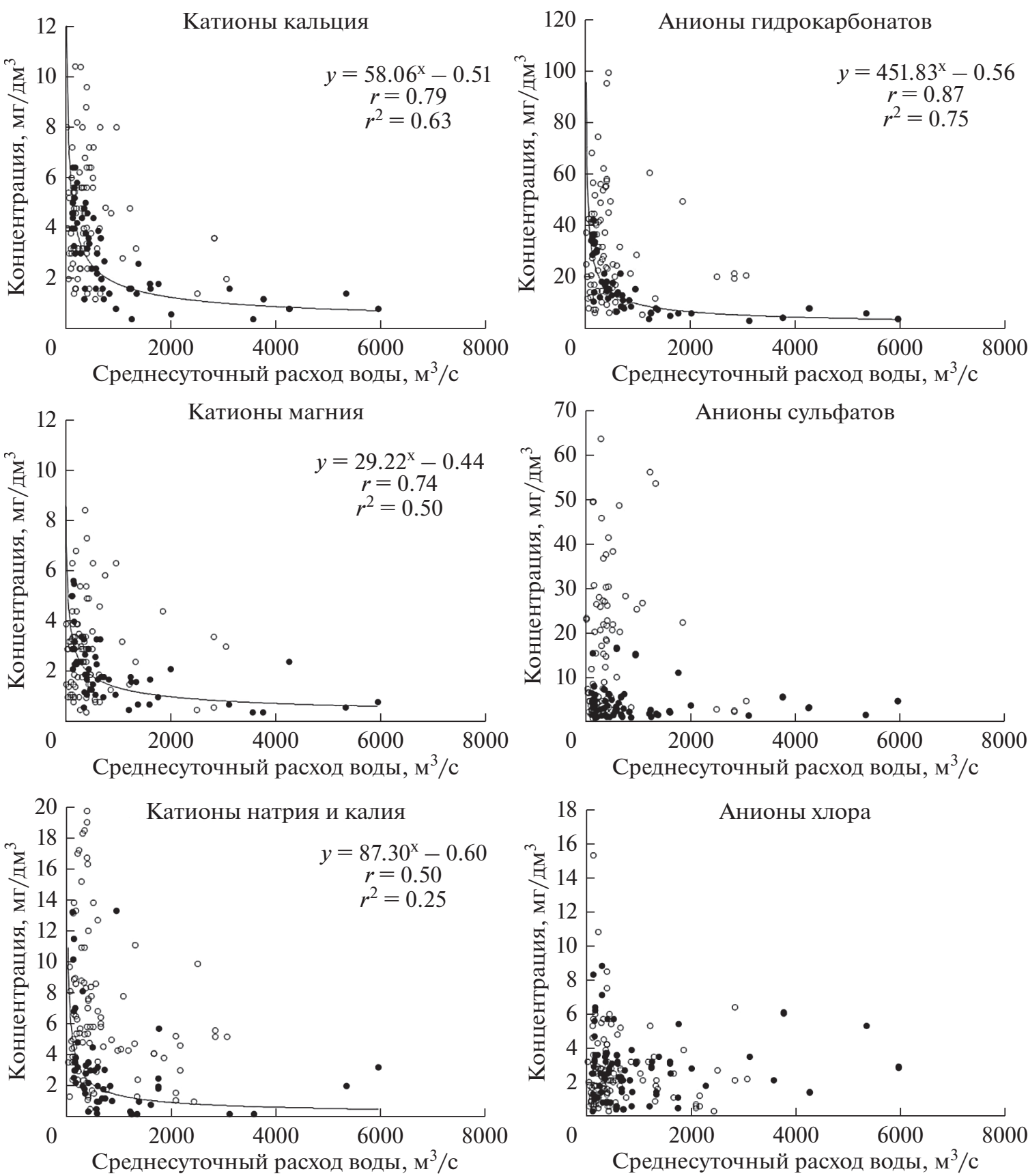

Рис. 1. Вид связи “расход воды-концентрация” для главных ионов в воде р. Надым в условно-фоновый и современный период (на диаграммах черные кружки соответствуют концентрациям, измеренным в условно-фоновый период, белые кружки - концентрациям, измеренным в современный период).

дах гидрокарбонатного класса этот механизм существенно ослаблен преимущественным связыванием и выпадением в осадок не сульфата кальция, а гидрокарбоната вследствие его меньшей растворимости. Второй механизм основан на биогенном накоплении серы в гумусовых слоях, что способствует ее задержке в солевом обороте. Однако низкие температуры и короткий период биологической активности существенно снижают важность процессов гумусообразования в природном обороте серы [3].

Несоответствие интенсивности поступления и выведения соединений серы из круговорота создает предпосылки для постепенного прироста ее концентраций в поверхностных водах. Вслед за изменением "антропогенно-чувствительных" ионов происходит смещение равновесия и для более 
Таблица 1. Параметры линейных трендов концентраций главных ионов в основные фазы гидрологического цикла

\begin{tabular}{l|l|c|c}
\hline \multirow{2}{*}{ Ион } & \multicolumn{3}{|c}{ Основные фазы $(1955-2016$ гг.) } \\
\cline { 2 - 4 } & весеннее половодье & летне-осенний период & зимняя межень \\
\hline \multirow{2}{*}{$\mathrm{Ca}^{2+}$} & $y=-102.2+0.053^{*} x ;$ & $y=-59.2+0.032 * x ;$ & $y=-94.9+0.051^{*} x ;$ \\
& $r=0.58$ при $p<0.001$ & $r=0.34$ при $p<0.04$ & $r=0.49$ при $p<0.001$ \\
$\mathrm{Mg}^{2+}$ & $y=-64.6+0.033^{*} x ;$ & $y=-56.9+0.030^{*} x ;$ & $y=-64.6+0.034^{*} x ;$ \\
& $r=0.53$ при $p<0.001$ & $r=0.44$ при $p<0.007$ & $r=0.46$ при $p<0.003$ \\
$\mathrm{Na}^{+}+\mathrm{K}^{+}$ & $y=-355.3+0.182^{*} x ;$ & $y=-488.1+0.249^{*} x ;$ & $y=-177.6+0.094^{*} x ;$ \\
& $r=0.66$ при $p<0.001$ & $r=0.72$ при $p<0.001$ & $r=0.28$ при р $>0.1$ \\
$\mathrm{HCO}_{3}^{-}$ & $y=-1044.5+0.535^{*} x ;$ & $y=-659.3+0.344 * x ;$ & $y=-668.9+0.356^{*} x ;$ \\
$\mathrm{SO}_{4}^{2-}$ & $r=0.64$ при $p<0.001$ & $r=0.4667$ при $p<0.004$ & $r=0.51$ при $p<0.001$ \\
& $y=-837.1+0.426^{*} x ;$ & $y=-1006.1+0.512 * x ;$ & $r=-642.5+0.328^{*} x ;$ \\
$\mathrm{Cl}^{-}$ & $r=0.71$ при $p<0.001$ & $r=0.79$ при $p<0.001$ & $r=0.60$ при $p<0.001$ \\
& $y=-76.1+0.040^{*} x ;$ & $y=-33.9+0.019 * x ;$ & $y=-51.5+0.027 * x ;$ \\
\hline
\end{tabular}

Примечание: в качестве зависимой переменной $x$ взят номер года.

устойчивых к влиянию человека ионов кальция и гидрокарбонатов.

Многолетние тренды главных ионов в р. Надым у г. Надым были оценены методом регрессионного анализа (табл. 1). Визуализация межгодовой динамики концентраций того или иного главного иона в зимнюю межень (подледный период), весеннее половодье и летне-осеннюю межень (период открытой воды) показала, что изменение химического состава речной воды проявляется для всех главных ионов, однако глубина этих изменений зависит от фазы водного режима, что позволяет с некоторой условностью предположить их причины.

Для катионов кальция прирост содержания наиболее выражен в период весеннего половодья и зимней межени и составляет около 0.5 мг/дм ${ }^{3}$ в десятилетие, а магния - около 0.3 мг/дм ${ }^{3}$ в десятилетие во все фазы водного режима. Динамика одновалентных катионов в зимнюю межень, напротив, в современный период сохраняется на уровне условно-фонового. В подледный период река переходит преимущественно на грунтовое питание, и причину прироста концентраций катионов, вероятно, следует искать в химическом составе подземных вод. Наиболее заметный прирост содержания катионов калия и натрия характерен для периода открытой воды: во время весеннего половодья (1.8 мг/дм ${ }^{3}$ в десятилетие) и особенно в летне-осеннюю межень (2.5 мг/дм ${ }^{3}$ в десятилетие).

Гидрокарбонаты прирастают преимущественно в весеннее половодье (5.4 мг/дм ${ }^{3}$ в десятилетие) и причина этого, возможно, заключается не только в увеличении растворения углекислого газа в период отрытой воды, но и за счет усиления процессов полного окисления органического ве- щества, которое в избытке поступает с водосбора с весенним стоком и сезонными надмерзлотными водами активного слоя.

Изменение сульфатов также проявляется во все фазы водного режима, но особенно заметным становится, как и для суммы одновалентных катионов, в период летне-осенней межени, когда разбавляющая способность р. Надым в сравнении с периодом весеннего половодья снижается (5.1 мг/дм ${ }^{3}$ в десятилетие). В весеннее половодье дополнительным источником сульфат-ионов может быть снежный покров, который зимой аккумулировал в себе атмосферно перенесенный сульфат. Однако прирост концентраций сульфатов отмечен и в период зимней межени, когда река переходит на подземное питание грунтовыми водами. Многолетняя динамика прироста концентраций хлоридов отмечена лишь в период весеннего половодья и составляет около 0.4 мг/дм ${ }^{3}$ в десятилетие.

Наблюдаемые тенденции позволяют предполагать возможность последующей техногенной метаморфизации химического состава воды р. Надым. Для характеристики этих изменений была проведена классификация воды реки по О.А. Алекину [1] за многолетний период (1979-2017 гг.) с использованием среднегодовых концентраций. Установлено, что, начиная с 2002 г., класс речных вод постепенно меняется с гидрокарбонатного на смешанный - сульфатно-гидрокарбонатный $(\mathrm{S}, \mathrm{C})$ или гидрокарбонатно-сульфатный $(\mathrm{C}, \mathrm{S})$. В катионном составе речных вод р. Надым изменения менее заметны. В соотношении катионов и анионов, которое определяет тип воды, также прослеживается трансформация химического состава с 2002 г.

Более заметны эти изменения при анализе среднемноголетних месячных концентраций. Класси- 
Таблица 2. Химический состав воды р. Надым, г. Надым по среднемноголетним месячным данным

\begin{tabular}{|c|c|c|c|c|c|c|c|}
\hline Месяц & $\begin{array}{l}\text { Доминирующие } \\
\text { анионы (класс) }\end{array}$ & $\begin{array}{c}\text { Доминирующие } \\
\text { катионы (группа) }\end{array}$ & Тип & Месяц & $\begin{array}{l}\text { Доминирующие } \\
\text { анионы (класс) }\end{array}$ & $\begin{array}{c}\text { Доминирующие } \\
\text { катионы (группа) }\end{array}$ & Тип \\
\hline \multicolumn{4}{|c|}{ 1979-2001 гг. } & \multicolumn{4}{|c|}{ 2002-2017 гг. } \\
\hline 4 & $\mathrm{C}$ & $\mathrm{Mg}, \mathrm{Na}, \mathrm{Ca}$ & I & 4 & $\mathrm{C}$ & $\mathrm{Na}$ & I \\
\hline 5 & $\mathrm{C}$ & $\mathrm{Na}, \mathrm{Ca}, \mathrm{Mg}$ & I & 5 & $\mathrm{C}, \mathrm{S}$ & $\mathrm{Na}$ & I \\
\hline 6 & $\mathrm{C}$ & $\mathrm{Na}$ & I & 6 & $\mathrm{C}, \mathrm{S}$ & $\mathrm{Na}$ & I \\
\hline 7 & $\mathrm{C}$ & $\mathrm{Na}, \mathrm{Mg}$ & I & 7 & $\mathrm{~S}, \mathrm{C}$ & $\mathrm{Na}$ & I \\
\hline 8 & $\mathrm{C}$ & $\mathrm{Na}$ & I & 8 & $\mathrm{~S}, \mathrm{C}$ & $\mathrm{Na}$ & II \\
\hline 9 & $\mathrm{C}$ & $\mathrm{Ca}, \mathrm{Na}$ & II & 9 & $\mathrm{C}, \mathrm{S}$ & $\mathrm{Na}$ & II \\
\hline 10 & $\mathrm{C}$ & $\mathrm{Na}, \mathrm{Mg}, \mathrm{Ca}$ & I & 10 & $\mathrm{C}, \mathrm{S}$ & $\mathrm{Na}$ & I \\
\hline
\end{tabular}

фикация химического состава за выделенные два периода (с 1979 по 2001 г. и с 2002 по 2017 г.) показана в табл. 2. Оценка химического состава воды с учетом сезонности показала трансформацию воды р. Надым не только в сторону смены химического состава воды с гидрокарбонатного класса группы кальция на смешанный сульфатно-гидрокарбонатный или гидрокарбонатно-сульфатный, но и доминирующего катиона - на натрий.

\section{ОБСУЖДЕНИЕ РЕЗУЛЬТАТОВ}

В истории освоения Севера Западной Сибири добыча нефти и газа играет ключевую роль, и интенсивная хозяйственная деятельность не могла не сказаться на водосборной территории бассейнов западносибирских рек. Однако помимо техногенных процессов в арктическом пространстве действует еще одна мощная сила - изменяющийся климат как общий фон, на котором происходят все процессы формирования химического состава речных вод. Поэтому целесообразно рассматривать влияние на химический состав воды р. Надым антропогенных и природных факторов. К первым относятся:

1) сброс неочищенных сточных вод, включая выпуски на рельеф;

2) расконсервация захоронений минерализованных пластовых и нефтепромысловых вод, а также амбаров бурового шлама;

3) атмосферный перенос загрязняющих веществ с их последующим выпадением в составе осадков на водосбор и вынос в поверхностные водоемы и водотоки.

Природные факторы могут быть связаны с последствиями глобального потепления климата. Положительный тренд атмосферных температур, последующее увеличение температур почв, подземных и поверхностных вод, а также глубины сезонного оттаивания активного слоя усиливают следующие процессы:
1) химическое выветривание подстилающих пород и усиление обмена минеральных солей с грунтовыми водами;

2) формирование сквозных таликов, дренирующих бессточные водоемы (в том числе и рассолы техногенного происхождения), которые прежде были изолированы от грунтовых вод слоем многолетней мерзлоты [20];

3) увеличение роли живого вещества в трансформации природных вод, которое связано как с усилением и пролонгацией периода биологической активности, так и с возрастанием содержания в природных водах органического вещества, ранее законсервированного в толще многолетней мерзлоты [19]. Его полное окисление проходит до конечных продуктов метаболизма - воды и углекислого газа, который, растворяясь, служит дополнительным источником производных угольной кислоты;

4) усиление растворения углекислого газа в воде как следствие повышения его парциального давления в атмосфере (согласно графику Килинга, опубликованному на сайте https://www.esrl.noaa.gov).

Другие природные факторы, например, усиление атмосферного переноса минеральных веществ с распыленными брызгами морской воды и проявление сгонно-нагонных явлений также могут трансформировать солевой состав природных вод, будучи косвенно связанными с температурными трендами и изменением климата.

Значительная изменчивость содержания главных ионов в поверхностных, пластовых, подземных водах и водах атмосферных осадков существенно затрудняет идентификацию и разделение факторов на антропогенные и природные [7].

Минерализованные пластовые и нефтепромысловые воды следует рассматривать как один из вероятных источников трансформации ионного состава поверхностных вод севера Западной Сибири, в том числе и р. Надым. Пластовые воды - подземные напорные воды, залегающие в нефтегазоносном горизонте. Нефтепромысловые воды - смесь пластовых 
Таблица 3. Гидрогеологические характеристики водоносных комплексов Надым-Тазовского междуречья (фрагмент таблицы по [11])

\begin{tabular}{|c|c|c|c|c|}
\hline \multirow{4}{*}{ Показатели } & \multicolumn{4}{|c|}{ Гидрогеологические комплексы } \\
\hline & Апт-альб-сеноманский & Неокомский & Верхнеюрский & Нижне-среднеюрский \\
\hline & \multicolumn{4}{|c|}{ солевой состав вод (по С.А. Щукареву) } \\
\hline & $\begin{array}{c}\mathrm{Cl}-\mathrm{Na} ; \\
\mathrm{Cl}-\mathrm{HCO}_{3}-\mathrm{Na}\end{array}$ & $\begin{array}{c}\mathrm{Cl}-\mathrm{Na} ; \\
\mathrm{Cl}-\mathrm{Na}-\mathrm{Ca} \\
\mathrm{Cl}-\mathrm{HCO}_{3}-\mathrm{Na}\end{array}$ & $\begin{array}{c}\mathrm{Cl}-\mathrm{Na} ; \\
\mathrm{Cl}-\mathrm{Na}-\mathrm{Ca} \\
\mathrm{Cl}-\mathrm{HCO}_{3}-\mathrm{Na}\end{array}$ & $\begin{array}{c}\mathrm{Cl}-\mathrm{Na} ; \\
\mathrm{Cl}-\mathrm{HCO}_{3}-\mathrm{Na}\end{array}$ \\
\hline $\mathrm{Ca}^{2+}, \mathrm{мг} / д \mathrm{M}^{3}$ & 271 & 410 & 638 & 306 \\
\hline $\mathrm{Mg}^{2+}$, мг/дм ${ }^{3}$ & 65 & 27 & 73 & 33 \\
\hline $\mathrm{Na}^{+}+\mathrm{K}^{+}, \mathrm{мг} /$ дм $^{3}$ & 5034 & 4028 & 7881 & 5494 \\
\hline $\mathrm{Cl}^{-}, \mathrm{мг} / д \mathrm{M}^{3}$ & 7987 & 6336 & 12891 & 8405 \\
\hline $\mathrm{SO}_{4}^{2-}, \mathrm{мг} /$ дм $^{3}$ & 22 & 42 & 42 & 82 \\
\hline $\mathrm{HCO}_{3}^{-}, \mathrm{мг} / д м^{3}$ & 615 & 875 & 920 & 1101 \\
\hline
\end{tabular}

и производственных вод хлоридно-натриевого состава, имеющие в Западной Сибири относительно невысокую минерализацию 9-15 г/дм³. Воздействие пластовых вод на поверхностные водотоки, протекающие по территориям нефтепромыслов, хорошо изучено на примере северной части Тюменской области. Основным индикатором такого воздействия является техногенная метаморфизация поверхностных вод вплоть до смены их класса: от очень маломинерализованной гидрокарбонатного класса кальциевой группы они перешли в хлоридный класс натриево-калиевой группы с умеренной жесткостью [16].

Техногенные геохимические потоки за счет высокоминерализованных пластовых вод при эксплуатации нефтяных и газовых месторождений характеризуются значительным поступлением ионов хлора и натрия. Воздействие их на воду p. Надым нельзя исключить по причине заметной многолетней положительной динамики содержания одновалентных катионов, особенно в летнеосенний период, однако и объяснить этой динамикой наблюдаемую в настоящее время трансформацию ионного состава воды р. Надым у г. Надым (особенно увеличение содержания сульфатионов), невозможно. Есть данные, подтверждающие потенциальные источники соединений серы в пластовых водах. Юрские пласты нефтегазоносных областей Западной Сибири, например, характеризуются довольно высоким содержанием пирита [18]. В нефтенасыщенных коллекторах пласта Ю $_{1}$ установлено около 5-8\% пирита, а в водонасыщенных - его количество возрастает до $20 \%[6]$.

Анализ химического состава вод верхнеюрского

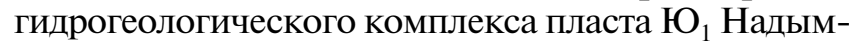

Тазовского междуречья был проведен Д.А. Новиковым [11]. Согласно результатам этой работы, солевой состав геологического горизонта, включающего в себя верхнеюрский комплекс, соответствует водам с повышенным содержанием не сульфатов, а хлоридов, а из катионов - натрия и калия. Сульфат-ион представлен в незначительных концентрациях (см. табл. 3).

Опосредованное влияние минерализованных вод антропогенного происхождения на территориях нефтепромыслов может быть связано с формированием техногенных водоемов и заболоченных участков на плоском мезорельефе при сбросе пластовых вод на рельеф. Как следствие, увеличивается минерализация грунтовых вод верхнего гидрологического этажа [16]. В свою очередь, это влечет за собой более отдаленные косвенные последствия, проявляющиеся в постепенной деградации многолетней мерзлоты, особенно в области таликов, поскольку солевые растворы имеют более низкую температуру замерзания [20]. Растепление грунтов по причине человеческой деятельности может быть вызвано и срезанием гусеничным транспортом верхнего теплоизолирующего слоя торфа. Вместе с протаиванием грунтов усиливаются процессы водной эрозии на нарушенных участках и активизируется поступление химических веществ из почвообразующих пород [7].

Влияние морских атмосферных осадков может являться основным источником поступления солей в поверхностные воды Западной Сибири [7]. Однако, учитывая характер изменений солевого состава р. Надым, с большей вероятностью можно было бы предполагать влияние атмосферного переноса соединений серы, образовавшихся в процессе сероочистки углеводородного сырья, а также дожигания некондиционных газоконден- 
сатных смесей в факельных установках [7]. Возможно, сток антропогенных соединений серы в поверхностные воды с весенними талыми водами обуславливает прирост их содержания в период половодья, однако в результате разбавления темпы прироста уступают периоду летне-осенней межени. Полностью подтвердить это предположение невозможно, так как хотя на территории НадымТазовского междуречья атмосферные осадки в сравнении с поверхностными водами сравнительно обогащены ионами сульфатов, их концентрации в среднем по Ямало-Ненецкому автономному округу по данным [10], не превышают 1.7 мг/дм³

Антропогенное влияние посредством привноса ионов с неочищенными сточными водами невелико. Так, по данным [17], в 2009 г. зарегистрированный сброс сульфатов со сточными водами на территорию водосбора р. Надым составил 133 т, а среднемноголетний объем стока р. Надым у г. Надым равен $15.043 \mathrm{kм}^{3}$. С учетом такого разбавления, увеличение концентраций соединений серы в речной воде за счет точечных источников не будет превышать 0.009 мг/дм³ .

Подземные воды, которые, вероятно, являются основной причиной наблюдаемых изменений химического состава поверхностных вод, в связи с наличием на исследуемой территории мощной и сложно построенной толщи многолетнемерзлых пород подразделяются на сезонно-талые надмерзлотные, межмерзлотные, подмерзлотные и воды сквозных таликов [10].

Сезонно-талые надмерзлотные воды являются буферным горизонтом между поверхностными и подземными межмерзлотными водами, имеют повсеместное распространение и часто играют определяющую роль в формировании химического состава вод зоны активного водообмена. По химическому составу надмерзлотные воды сезонно-талого слоя и несквозных таликов преимущественно гидрокарбонатные кальциевые, магниевые, гидрокарбонатные натриевые с минерализацией 0.06-0.12 г/л [10], так как приурочены к отложениям четвертичного возраста различного генезиса [17]. Глубина залегания подошвы грунтовых вод определяется глубиной сезонного протаивания, и если в торфе она не превышает 0.50.6 м, то в минеральных грунтах может достигать 1.5-2.0 м. Надмерзлотные воды существуют недолго. Они возникают в июне с началом протаивания сезонно-талого слоя, в течение лета могут периодически пропадать из-за недостатка питания, а уже в ноябре полностью промерзают. Ввиду большой заболоченности территории они обогащены органическими веществами [17].

Межмерзлотные воды сообщаются с надмерзлотными через “таликовые окна”, а существование внутримерзлотного водоносного горизонта в основном определяется геокриологическими услови- ями. Основными природными факторами, определяющими ионно-солевой и газовый состав подземных межмерзлотных вод, являются разложение растений, жизнедеятельность микроорганизмов и (в меньшей степени) выщелачивание горных пород. Антропогенное влияние осуществляется через поступление загрязняющих вешеств из верхних горизонтов через талики. Разгрузка водоносного горизонта происходит в речную сеть [10].

В работе [10] приводятся результаты первичного опробования химического состава подземных вод межмерзлотных горизонтов Уренгойского нефтегазоконденсатного месторождения. Состав этих вод действительно значительно ближе к ионному составу воды р. Надым и может влиять на его формирование. Но, несмотря на близость химического состава межмерзлотных подземных и поверхностных вод, объяснить наблюдаемую динамику только их влиянием невозможно, так как на современном этапе среднее содержание ионов в межмерзлотных водах для различных участков Уренгойского месторождения стало ниже: хлориды - 1.6 мг/дм ${ }^{3}$, сульфаты не обнаружены, гидрокарбонат-ион - 18.8 мг/дм ${ }^{3}$, катионов калия 0.7 мг/дм ${ }^{3}$, натрия - 3.1 мг/дм ${ }^{3}$, магния 2.1 мг/дм ${ }^{3}$, кальция - 3.1 мг/дм ${ }^{3}$.

Возможно, причиной положительного тренда содержания сульфатов в р. Надым является их эмиссия из буровых шламов в сезонноталые надмерзлотные воды, что обеспечивает их избыточное поступление в период открытой воды (в период половодья сульфаты при этом разбавляются и их прирост в сравнении с периодом летне-осенней межени ниже), а также миграция сульфатиона через талики в межмерзлотные горизонты, разгружающие свои воды в р. Надым, что обеспечивает прирост поступления сульфатов в подледный период. Антропогенная нагрузка усугубляется происходящими глобальными процессами, так как открытие таликов стимулируется потеплением и более глубоким протаиванием почв, прогревом надмерзлотных вод на участках залегания с поверхности хорошо проницаемых пород. Такие надмерзлотные воды очень тесно связаны с межмерзлотными, отепляя их и способствуя их распространению [17].

В процессе добычи нефти и газа с отходами бурения в наземные и водные экосистемы попадает значительное количество загрязняющих веществ. Основная часть бурового шлама (пород, смешанных с буровым раствором) складируется в шламовых амбарах [15]. Для крайнего Севера Западной Сибири многолетняя мерзлота выполняет роль гидроизоляционного экрана, однако ее деградация постепенно может приводить к увеличению фильтрации содержимого шламовых амбаров в грунт. Так по данным программы мониторинга CALM, приведенным на сайте 


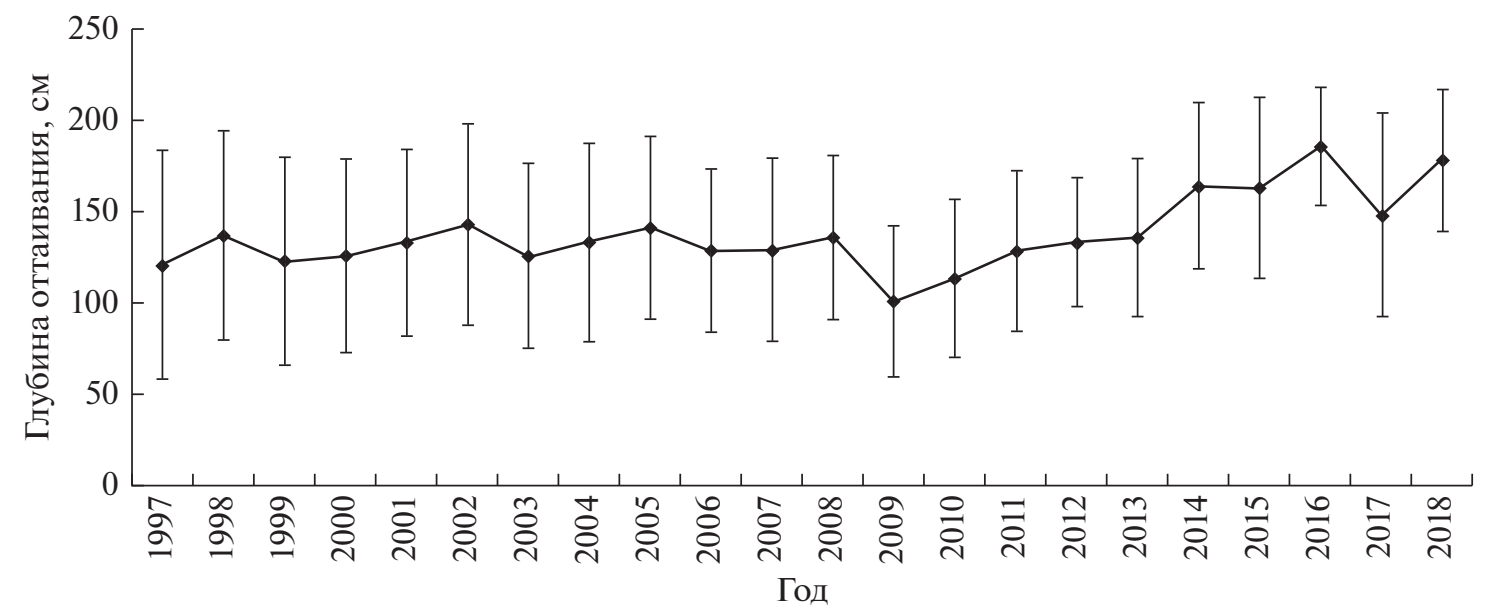

Рис. 2. Динамика глубины сезонного оттаивания грунта у г. Надым (на диаграмме приведены средние значения со стандартным отклонением).

https://www2.gwu.edu/ calm/data/north.html, c c 2009 г. глубина сезонного оттаивания грунта у г. Надым действительно характеризуется возрастающим трендом (рис. 2).

Субстрат и амбарная вода содержат значительное количество ионов в сравнении с природными водами. По данным [15], в водных вытяжках отходов бурения обнаруживаются: катионы кальция в концентрациях в среднем 123.4 ммоль/100 г, катионы магния - 46.6 ммоль/100 г, анионы сульфатов - 3194.8 мг/кг, хлорид-ионы - 228.2 мг/кг. В зависимости от типа бурового раствора, содержание сульфатов в нем и, как следствие, в буровом шламе, может быть существенно выше прочих главных ионов. Явление фильтрации и утечки жидких отходов из шламовых амбаров хорошо известно и классифицируется как постоянный источник загрязнения окружающей среды. Помимо этого возможно затопление территории буровой вследствие паводка в период весеннего половодья или интенсивного таяния снегов и разлив при этом содержимого шламовых амбаров, но такой источник загрязнения является временным.

\section{ЗАКЛЮЧЕНИЕ}

Таким образом, предпосылки техногенной метаморфизации ионного состава воды р. Надым заключаются в увеличении ее минерализации, в первую очередь за счет прироста концентраций сульфатов, а также суммы ионов натрия и калия. Так как сброс неочищенных сточных вод, включая выпуски на рельеф, атмосферный перенос загрязняющих веществ с их последующим выпадением в составе осадков на водосбор и вынос в поверхностные водоемы и водотоки не могут вызвать таких характерных эффектов, вероятную их причину следует искать в процессе расконсер- вации захоронений бурового шлама в результате деградации многолетней мерзлоты - естественного гидроизоляционного экрана шламовых амбаров на буровых площадках Крайнего Севера. В свою очередь, деградация многолетней мерзлоты обусловлена положительными сезонными трендами атмосферных температур и, как следствие, сезонным увеличением температур почв, глубины сезонного оттаивания активного слоя, подземных и поверхностных вод.

\section{ФИНАНСИРОВАНИЕ}

Исследование выполнено при финансовой поддержке РФФИ в рамках научного проекта № 18-05-60165.

\section{FUNDING}

The study was financially supported by the grant received from the RFBR, no. 18-05-60165.

\section{СПИСОК ЛИТЕРАТУРЫ}

1. Алекин А.О. Общая гидрохимия (Химия природных вод). Ленинград: Гидрометеорологическое изд-во, 1948. $208 \mathrm{c}$.

2. Брехунцов А.М. История освоения Западно-Сибирской нефтегазоносной провинции и вопросы воспроизводства минерально-сырьевой базы углеводородного сырья на современном этапе // Нефтегазовая геология. 2010. № 3. С. 20-25.

3. Гнусин Н.П. Прогноз увеличения стока сульфатных ионов рек территории Советского Союза до 2000 г.: Сб. науч. тр. ГХИ "Гидрохимические материалы. Методы химического анализа и процессы самоочищения природных вод”. T. LIII. Л.: Гидрометеоиздат, 1970. С. 125-130.

4. ГОСТ Р ИСО 16269-4-2017. Статистические методы. Статистическое представление данных. Ч. 4. 
Выявление и обработка выбросов. М.: Стандартинформ, 2017. 53 с.

5. Гусев Е.М., Насонова О.Н., Джоган Л.Я., Айзель Г.В. Моделирование формирования стока рек и снежного покрова на севере Западной Сибири // Водные ресурсы. 2015. Т. 42. № 4. С. 460-467. https://doi.org/10.1134/S0097807815040065

6. Кропачев Н.М., Рысев В.В., Кориков А.П., Корнев А.Н., Мордвинцев М.В., Скачек К.Г. Методика литологофациального моделирования пласта Ю $_{1}$ васюганской свиты в пределах Сургутского свода по данным сейсморазведки и бурения // Технологии сейсморазведки. 2004. № 2. С. 81-91.

7. Кукушкин С.Ю. Индикаторы антропогенной нагрузки на природно-территориальные комплексы при освоении нефтегазоконденсатных месторождений севера Западной Сибири. Дис. ... канд. геогр. наук. СПб.: СПбГУ, 2016. 200 с.

8. Максимова М.П. Воздействие техногенеза на гидросферу. Методика оценки антропогенного химического речного стока в моря // Вестн. МГОУ. Сер. Естественные науки. 2012. № 2. С. 89-96.

9. Московченко Д.В. Геохимия ландшафтов ЗападноСибирской равнины. Автореф. дис. ... Д-ра геогр. наук. СПб.: Ин-т проблем освоения Севера СО PAH, 2010. 394 c.

10. Торопов Г.В., Бешенцев В.А. Особенности формирования химического состава природных вод на территории Уренгойского нефтегазодобывающего региона (на примере Уренгойского НГКМ) // Вестн. ТюмГУ. Сер. Науки о Земле. 2013. № 4. C. 115-124.

11. Новиков Д.А. Геохимия подземных вод нефтегазоносных отложений Надым-Тазовского междуречья. Автореф. дис. ... канд. геол.-минерал. наук. Томск: Ин-т геологии нефти и газа СО РАН, 2002. $248 \mathrm{c.}$

12. Государственный доклад “О состоянии и использовании минерально-сырьевых ресурсов Российской Федерации в 2015 г.” / гл. ред. Е.А. Киселев. М., 2016. 344 c.
13. Опекунов А.Ю., Опекунова М.Г., Кукушкин С.Ю., Ганул А.Г. Оценка экологического состояния природной среды районов добычи нефти и газа в Ямало-Ненецком автономном округе // Вестн. СПБГУ. Сер. 7. Геология, география. 2012. № 4. С. 87-101.

14. Ресурсы поверхностных вод СССР. Алтай и Западная Сибирь. Нижний Иртыш и Нижняя Обь. Т. 15. Вып. 3. Ленинград: Гидрометеоиздат, 1973. 424 с.

15. Савичев О.Г., Бернатонис П.В., Бернатонис В.К. Геохимические условия размещения и утилизации отходов бурения в торфяно-болотных геосистемах Сибири // Вестн. ТГУ. 2013. № 375. С.183-186.

16. Сванидзе И.Г. Воздействие минерализованных пластовых вод на ландшафты речных долин южной тайги Западной Сибири (на примере юга Тюменской области). Дис. .... канд. геогр. наук. Барнаул: ТюмГУ, 2015. 155 с.

17. Схема комплексного использования и охраны водных объектов бассейна реки Надым. Кн. 1. Общая характеристика речного бассейна. 2014. 71 с.

18. Штырляева A.A. Региональная корреляция и реконструкция условий формирования продуктивных пластов $Ю_{1}$ и $Ю_{2}$ средней и верхней юры Надым-Пурской и среднеобской НГО (Западно-Сибирский нефтегазоносный бассейн) // Вестн. ВГУ. Сер. Геология. 2016. № 2. С. 40-46.

19. Weiss N., Kaal J. Characterization of labile organic matter in Pleistocene permafrost (NE Siberia), using Thermally assisted Hydrolysis and Methylation (THMGC MS) // Soil Biol. and Biochem. 2018. V. 117. P. 203-213.

20. Woo M.-K. Permafrost hydrology. Berlin: SpringerVerlag, 2012. 564 p.

21. Zakharova E.A., Kouraev A.V., Biancamaria S., Kolmakova M.V., Mognard N.M., Zemtsov V.A., Kiprotin S.N., Decharme B. Snow Cover and Spring Flood Flow in the Northern Part of Western Siberia (the Poluy, Nadym, Pur, and Taz Rivers) // J. Hydrometeorol. 2011. V. 12. P. 1498-1511.

\title{
Preconditions to Technogenic Metamorphization of Nadym River Water Ionic Composition in Conditions of Global Climate Change
}

\author{
${ }^{1}$ Hydrochemical Institute, Rostov-on-Don, Russia \\ ${ }^{2}$ Southern Federal University, Rostov-on-Don, Russia \\ \#e-mail: a.danilenko@gidrohim.com \\ \#\#-mail:l.kosmenko@gidrohim.com \\ \#\#\#-mail: olgare1@mail.ru \\ \#\#\#\#-mail: m.kondakova@gidrohim.com
}

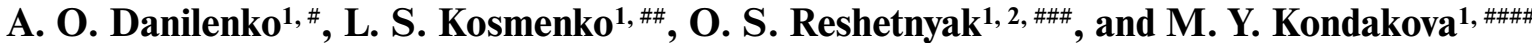

Received February 4, 2019; revised May 13, 2019; accepted October 3, 2019

The hydrochemical regime changes of Nadym River near city of Nadym from the start of regular observations in 1955 till 2016 in conditions of anthropogenic impact and global climate change was reviewed. Shown, that the relations between the major ion concentrations (ions of sodium and potassium, calcium, magnesium, chlorides, sulfates and bicarbonates) and water discharge from 1980 are getting weaker down to insignificant. Likewise, disturbances the natural ratio between the major ions, which most pronounced in a strong positive trend of the sulfate ions content in river water, are arise. The data on the long-term dynamics of the main ions 
in the main phases of the hydrological regime (spring high water, summer-autumn and winter low water) are presented. The probable causes of the observed preconditions to technogenic metamorphization of Nadym River ionic composition are considered: impact of untreated sewage discharge, atmospheric transport of anthropogenic and natural sulfur compounds, and pollution by mineralized formation waters. It has been suggested that the sulfates increased during all phases of the hydrological regime, including the winter low water, is associated with contamination of ground waters as a result of filtration and leakage of drilling waste from slurry barns. Probably, it occurs due to the degradation of their natural waterproofing layer of permafrost rocks under the influence of global climate change.

Keywords: Nadym River, ionic composition of river water, technogenic metamorphization, anthropogenic impact, global climate change

\section{REFERENCES}

1. Alekin A.O. Obshchaya gidrokhimiya (Khimiya prirodnykh vod) [Hydrochemistry (Chemistry of Natural Waters)]. Leningrad: Gidrometeorol. I-vo Publ., 1948. $208 \mathrm{p}$.

2. Brekhuntsov A.M. Historical development of the West Siberian petroleum province and hydrocarbon resources replacement issues at the present stage. Neftegaz. Geol., 2010, no. 3, pp. 20-25. (In Russ.).

3. Gnusin N.P. Forecast of increase in sulphate ions runoff on the Soviet Union territory until 2000. In Gidrokhimicheskie materialy. Metody khimicheskogo analiza $i$ protsessy samoochishcheniya prirodnykh vod [Hadrochemical Materials. Methods of Chemical Analysis and Processes of Natural Waters Self-Purification]. Leningrad: Gidrometeorol. I-vo Publ., 1970, vol. LIII, pp. 125-130. (In Russ.).

4. GOST R ISO 16269-4-2017. Statistical Methods. Statistical Data Presentation. Part 4. Detection and Treatment of Outliers. Moscow: Standartinform Publ., 2017. $53 \mathrm{p}$.

5. Gusev E.M., Nasonova O.N., Dzhogan L.Ya., Ayzel G.V. Simulating the formation of river runoff and snow cover in the northern West Siberia. Water Resour., 2015, vol. 42, no. 4, pp. 460-467. doi 10.1134/S0097807815040065

6. Kropachev N.M., Rysev V.V., Korikov A.P., Kornev A.N., Mordvintsev M.V., Skachek K.G. Methods of lithological facies modeling of the $\mathbf{J}_{1}$ formation of the Vasyugan formation within the Surgut arch according to seismic survey and drilling data. Tekhnologii Seismorazvedki, 2004, no. 2, pp. 81-91. (In Russ.).

7. Kukushkin S.Yu. Indicators of anthropogenic load on natural-territorial complexes during the development of oil and gas condensate fields of the north of Western Siberia. Cand. Sci. (Geogr.) Dissertation. St. Petersburg: St. Petersburg State Univ., 2016. 200 p.

8. Maksimova M.P. Effect of technogenesis on hydrosphere. Methods for evaluating chemical anthropogenic river runoff to the sea. Vestn. MGOU. Ser. Estestvennye Nauki, 2012, no. 2, pp. 89-96. (In Russ.).

9. Moskovchenko D.V. Geochemistry of the West Siberian plain landscapes. Extended Abstract of Doct. Sci. (Geogr.) Dissertation. St. Petersburg: Inst. Probl. Northern Dev., SB RAS, 2010. 394 p.

10. Toropov G.V., Beshentsev V.A. Features of the chemical composition's formation of natural water in the Urengoy oil and gas production area (the case of the Urengoy oil and gas condensate field). Vestn. Tyumenskogo Gos. Univ., Ser. Nauki o Zemle, 2013, no. 4, pp. 115-124. (In Russ.).
11. Novikov D.A. Geochemistry of groundwater in oil and gas deposits of the Nadym-Tazovsky interfluve. Extended Abstract of Cand. Sci. (Geol.-Min.) Dissertation. Tomsk: Inst. of Petroleum Geology and Geophysics, SB RAS, 2002. 248 p.

12. Gosudarstvennyi doklad "O sostoyanii i ispolzovanii mineral'no-syr'evykh resursov Rossiiskoi Federatsii v 2015 godu" [State Report on the Status and Using Mineral Resources of the Russian Federation in 2015]. Kiselev E.A., Ed. Moscow, 2016. 344 p.

13. Opekunov A.Yu., Opekunova M.G., Kukushkin S.Yu., Ganul A.G. Environmental assessment in the oil and gas production areas of the Yamalo-Nenets Autonomous District. Vestn. S.-Peterb. Gos. Univ., Ser. 7: Geol., Geogr., 2012, no. 4, pp. 87-101. (In Russ.).

14. Resursy poverkhnostnykh vod SSSR. Altai i Zapadnaya Sibir'. Nizhnii Irtysh i Nizhnyaya Ob' [Surface Water Resources of the USSR. Altai and Western Siberia. Lower Irtysh and Lower Ob]. Leningrad: Gidrometeoisdat Publ., 1973, vol. 15, no. 3, 424 p.

15. Savichev O.G., Bernatonis P.V., Bernatonis V.K. Geochemical conditions of the drilling waste's allocation and utilization in peat-bog geosystems of Siberia. Vestn. Tomsk. Gos. Univ., 2013, no. 375, pp. 183-186. (In Russ.).

16. Svanidze I.G. The impact of mineralized formation waters on the river valleys landscapes of the southern taiga in Western Siberia (using the example of the South of the Tyumen region). Cand. Sci. (Geogr.) Dissertation. Barnaul: Tyumen State Univ., 2015. 155 p.

17. Schemes of Integrated Use and Protection of Water Bodies in the Nadym River Basin. Book 1: General Characteristics of the River Basin. 2014. 71 p.

18. Shtyrlyaeva A.A. The regional correlation and reconstruction of the formation's condition of the Middle and Apper Jurassic reservoir rocks $\mathbf{J}_{1}$ and $\mathbf{J}_{2}$ by NadymPurskaya and Sredneobskaya oil and gas fields (West Siberian petroleum basin). Vestn. Voronezh. Gos. Univ., Ser. Geol., 2016, no. 2, pp. 40-46. (In Russ.).

19. Weiss N., Kaal J. Characterization of labile organic matter in Pleistocene permafrost (NE Siberia), using Thermally assisted Hydrolysis and Methylation (THMGC MS). Soil Biol. Biochem., 2018, vol. 117, pp. 203-213.

20. Woo M.-K. Permafrost Hydrology. Berlin: SpringerVerlag, 2012. $564 \mathrm{p}$.

21. Zakharova E.A., Kouraev A.V., Biancamaria S., Kolmakova M.V., Mognard N.M., Zemtsov V.A., Kiprotin S.N., Decharme B. Snow cover and spring flood flow in the Northern part of Western Siberia (the Poluy, Nadym, Pur, and Taz Rivers). J. Hydrometeorol, 2011, vol. 12, pp. $1498-1511$.

doi 10.1175/JHM-D-11-017.1 